\title{
New mathematical modelling for grain size distribution adjustment in concrete
}

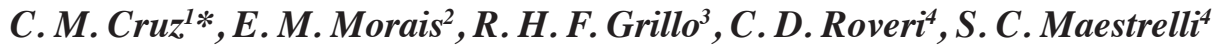 \\ ${ }^{1}$ University of São Paulo, FZEA, Av. Duque de Caxias Norte 225, Pirassununga, SP, Brazil \\ ${ }^{2}$ Institute for Theoretical Physics, UNESP, São Paulo, SP, Brazil \\ ${ }^{3}$ Federal Institute of Sul de Minas, Pouso Alegre, MG, Brazil \\ ${ }^{4}$ Federal University of Alfenas, Poços de Caldas, MG, Brazil
}

\begin{abstract}
Concrete used in civil engineering is a composite obtained from the combination of coarse and fine aggregates, cement and water, and its cost and quality are normally associated to the proportion of its constituents (ceramic formulation), as well as the reduction of water consumption. The aggregates used in concrete may have diverse origins, and the syenite extracted at Pedra Branca Alkaline Massif is one of the materials that can be used for this substitution. In order to do so, a reference formulation of concrete was calculated and optimized using the mathematical models of Andreasen, and syenite was added substituting 25,50,75 and 100\% of the fine aggregate. In order to maintain the original granulometric distribution, an algorithm was developed to compensate the different particle size distributions. The grain size correction guaranteed the maintenance of the original properties of the concrete, reaching values of mechanical strength above $35 \mathrm{MPa}$.
\end{abstract}

Keywords: concrete, packing equations, algorithm, syenite, mechanical properties.

\section{INTRODUCTION}

Concrete is one of the cheapest and most easily produced materials in the world, besides being one of the most common structural materials. Concrete may be considered a composite, in which the matrix is formed by the combination of cement and water, in order to form a binder, and the reinforcement is presented in the form of particulate and fragmented aggregates, from which natural sand, gravel, boulder, hail, among others, can be highlighted $[1,2]$. The aggregates may be classified as coarse or fine. Coarse aggregates refer to the material with a grain size larger than $4.75 \mathrm{~mm}$ (sieve 4 mesh). The fine aggregate, together with the binder system (cement and water), forms the mortar, while with the coarse aggregates concrete is formed [1]. The choice of the aggregate is important, since it has an impact in cost and workability of the fresh concrete, and may also influence mechanical strength, dimensional stability, and durability of the hardened concrete. The granulometric distribution affects directly the workability of the concrete, seeing that it is directly linked to particle packing $[1,3]$. In addition, the roundness of the particles must also be considered, i.e. the relative sharpness or the angularity of the edges and/or corners of a particle [4]. The rounder the particle, the better its packing in the mix. However, a higher roughness of the aggregate surface and angularity of the edges/corners may lead to better anchoring between the particles; thus, there must be an equilibrium in order to have good particle packing, but also fine anchoring [5].

The scarcity of some raw materials such as sand, as well

*carolmoraescruz@gmail.com

(D) https://orcid.org/0000-0001-5712-4766 as an attempt of diminishing the impact of urbanization on the environment, has led to several researches on the incorporation of disposals in concrete, such as tire rubber, coal ashes and casting sand [6-8]. Syenite is an igneous rock with high levels of sodic and potassic feldspars, which may contain $80 \%$ to 95\% of feldspars and feldspathoids in its totality [9]. The syenite from 'Maciço da Pedra Branca', in Minas Gerais State, Brazil, has been used as ornamental rocks due to its brown color resulting from the mineralogical composition. Due to the low exploitation during its extraction, this material is currently being accumulated in the environment; thus, it was evaluated for the substitution of fine gravel in concretes.

The adequate formulation of concretes, resulting in efficient packing of its particles, exerts a direct effect in many of its properties. In the case of concretes, as well as structural ceramics, electronics, nuclear and powder metallurgy, for example, it is desirable that the product presents a dense packing [5]. There are several models to determine the ideal packing of particles. The purpose of this work was to develop a formulation of concrete using Andreasen's model and, subsequently, substitute fine gravel by syenite. Since fine gravel and syenite had different grain size distributions, an algorithm was developed in order to keep the original distribution as determined by Andreasen's equation.

\section{MATERIALS AND METHODS}

Andreasen's method: this model considers the particle distributions as continuous. In his model, in an ideal particle packing, the neighborhood of two specific particles with very different sizes presents conditions of similarity, which defines the grain size distribution in terms of a power law, as 
indicated in Eq. A [5]:

$$
\mathrm{CPFT}=\left(\frac{\mathrm{D}_{\mathrm{p}}}{\mathrm{D}_{\mathrm{L}}}\right)^{\mathrm{q}} \cdot 100
$$

in which CPFT is the accumulated percentage of particles smaller than $\mathrm{D}_{\mathrm{p}}, \mathrm{D}_{\mathrm{p}}$ is the particle diameter, $\mathrm{D}_{\mathrm{L}}$ is the diameter of the larger particle and $\mathrm{q}$ is the module or distribution coefficient. The Andreasen distribution with better possible packing is, theoretically, the one using $\mathrm{q}=0.37$ [5].

Algorithm: given a determinate reference formulation of concrete, composed by fine and coarse gravel, it is desirable the use of disposal to replace a determinate proportion of fine gravel, keeping the grain size distribution of the concrete as close as possible to the original distribution as calculated using the packing equation of Andreasen. Grain size distribution curves of all compounds must be taken in the same sieves, and with the same quantity $\mathrm{N}$ of sieves, and they are represented by vectors containing the cumulative distribution. Consider $\overrightarrow{\mathrm{CS}}$ the cumulative grain size distribution of the reference concrete; the same way, $\overrightarrow{\mathrm{P}}$ is the distribution of fine gravel, $\overrightarrow{\mathrm{B}}$ is the one for coarse gravel and $\overrightarrow{\mathrm{S}}$ is the distribution for the substituting material. Thus, the distribution of the concrete containing the substituting material is:

$$
\overrightarrow{\mathrm{CS}}=\alpha \overrightarrow{\mathrm{P}}+\beta \overrightarrow{\mathrm{B}}+\gamma \overrightarrow{\mathrm{S}}
$$

in which the coefficients $\alpha, \beta$, and $\gamma$ designate the proportions of fine gravel, coarse gravel and substituting material, respectively. These variables must respect the constraint:

$$
\alpha+\beta+\gamma=1
$$

reducing one degree of freedom of the optimization problem. The proportion of substitution $\omega$ is pre-determined so that the engineer has total control in order to minimize production cost or maximize logistical advantages in the supply of raw materials. It is defined as:

$$
\omega=\frac{\gamma}{\beta+\gamma}=\frac{\gamma}{1-\alpha}
$$

which supply another constraint to the optimization problem, diminishing another degree of freedom of the problem. To optimize, it was used the method of ordinary least squares:

$$
0^{2}=\sum_{\mathrm{i}=1}^{\mathrm{N}}\left(\overrightarrow{\mathrm{CS}_{\mathrm{i}}}-\overrightarrow{\mathrm{C}_{\mathrm{i}}}\right)^{2}=\sum_{\mathrm{i}=1}^{\mathrm{N}}\left(\alpha \overrightarrow{\mathrm{P}_{1}}+\beta \overrightarrow{\mathrm{B}_{1}}+\gamma \overrightarrow{\mathrm{S}_{1}}-\overrightarrow{\mathrm{C}_{\mathrm{i}}}\right)^{2}
$$

Using Eqs. $B$ and $C$ to rewrite $\beta$ and $\gamma$ in terms of $\alpha$ :

$$
\left\{\begin{array}{l}
\beta=(1-\alpha)(1-\omega) \\
\gamma=(1-\alpha) \omega
\end{array}\right.
$$

the least squares sum may be written as:

$0^{2}=\sum_{\mathrm{i}=1}^{\mathrm{N}}\left(\alpha \overrightarrow{\mathrm{W}_{1}}-\overrightarrow{\mathrm{V}_{1}}\right)^{2}=\alpha^{2} \sum_{\mathrm{i}=1}^{\mathrm{N}}{\overrightarrow{\mathrm{W}_{1}}}_{1}^{2}+\sum_{\mathrm{i}=1}^{\mathrm{N}} \overrightarrow{\mathrm{V}}_{1}^{2}-2 \alpha \sum_{\mathrm{i}=1}^{\mathrm{N}} \overrightarrow{\mathrm{W}_{1}} \overrightarrow{\mathrm{V}}_{1}$

being $\overrightarrow{\mathrm{W}_{1}}$ and $\overrightarrow{\mathrm{V}_{1}}$ elements of vectors defined by:

$$
\left\{\begin{array}{l}
\vec{W}=\vec{P}-\vec{B}+\omega(\vec{B}-\vec{S}) \\
\vec{V}=\vec{C}-\vec{B}+\omega(\vec{B}-\vec{S})
\end{array}\right.
$$

Minimizing Eq. $G$ leads to:

$$
\frac{\partial \mathrm{O}^{2}}{\partial \alpha}=2 \alpha \sum_{\mathrm{i}=1}^{\mathrm{N}} \overrightarrow{\mathrm{W}}_{1}^{2}-2 \sum_{\mathrm{i}=1}^{\mathrm{N}} \overrightarrow{\mathrm{W}}_{1} \overrightarrow{\mathrm{V}}_{1}=0
$$

Thus, the optimum proportion of fine gravel is:

$$
\alpha=\frac{\sum_{\mathrm{i}=1}^{\mathrm{N}} \overrightarrow{\mathrm{W}}_{1} \overrightarrow{\mathrm{V}}_{1}}{\sum_{\mathrm{i}=1}^{\mathrm{N}} \overrightarrow{\mathrm{W}}_{1}^{2}}
$$

and the optimum proportions of coarse gravel and substituting material may be calculated by Eq. F.

Experimental: it was used as raw materials gravel in grains and powder from Pouso Alegre region as coarse and fine aggregates, respectively, syenite from Pedra Branca Alkaline Massif, cement type CP II-E 32 (Holcim Brazil) and superplasticizer additive Glenium 51 (Basf), with density of 1067 to $1107 \mathrm{~kg} / \mathrm{m}^{3}$. Initially, the aggregates were classified according to their physical properties, through the determination of bulk density, solid bulk density, water absorption and apparent porosity using the Archimedes' method. The grain size distribution of the aggregates was determined using sieves with openings between 25 and $0.15 \mathrm{~mm}$ for the coarse aggregate and between 9.5 and $0.15 \mathrm{~mm}$ for the fine aggregates. It was also performed semiquantitative chemical analysis by $\mathrm{X}$-ray fluorescence and determined the $\mathrm{pH}$ for each aggregate.

The reference formulation of the concrete, denominated $\mathrm{C} 1$, was calculated using the equation of Andreasen. The amount of cement used was calculated in order to obtain mechanical strength of $35 \mathrm{MPa}$ after 28 days [10]. It was calculated four formulations with the substitution of fine gravel by syenite, in the proportions of 25\% (C1-25), 50\% (C1-50), 75\% (C1-75) e 100\% (C1-100). The proportion of the aggregates was determined using the algorithm previously detailed, using as a target the accumulated grain size distribution of formulation $\mathrm{C} 1$. The formulations obtained are listed in Table I. The content of additive was fixed at $0.4 \mathrm{wt} \%$ of cement, due to good results presented in [10], and the water content was determined at the moment of mixing, in order to obtain a self-compacting concrete. For each formulation, it was analyzed the properties in the fresh and hardened state. For the fresh concrete, it was performed a visual analysis of the cohesion through a slump test, according to Brazilian standard NBR NM 67 [11]. Then, cylindrical specimens of $0.01 \mathrm{~m}$ in diameter and $0.02 \mathrm{~m}$ in height were prepared for evaluation of compressive strength of the hardened concrete. For each of the formulations analyzed, 6 specimens were prepared for each age (7, 14 and 28 days). After $24 \mathrm{~h}$ of casting, curing was made through the immersion of the specimens in water with an average temperature of $21{ }^{\circ} \mathrm{C}$ until evaluation of compressive strength. Preparation of specimens and evaluation of compressive strength were performed 
Table I - Concrete formulations $(\mathrm{kg})$ with syenite additions.

\begin{tabular}{lccccc}
\hline Raw material & $\mathrm{C} 1$ & $\mathrm{C} 1-25$ & $\mathrm{C} 1-50$ & $\mathrm{C} 1-75$ & $\mathrm{C} 1-100$ \\
\hline Coarse gravel & 40.383 & 40.463 & 40.149 & 39.893 & 39.701 \\
Fine gravel & 35.112 & 26.274 & 17.673 & 8.901 & - \\
Syenite & - & 8.758 & 17.673 & 26.702 & 35.794 \\
Cement & 27.696 & 27.696 & 27.696 & 27.696 & 27.696 \\
Water & 11.130 & 11.130 & 11.130 & 11.130 & 11.130 \\
Additive & 0.111 & 0.111 & 0.111 & 0.111 & 0.111 \\
\hline
\end{tabular}

according to Brazilian standards NBR 5738:2015 [12] and NBR 5739:2007 [13].

\section{RESULTS AND DISCUSSION}

Aggregate characterization: the accumulated grain size distribution data of syenite may be seen in Table II, comparatively with those of coarse and fine gravels. The results of the physical tests are presented in Table III. It can be seen that the grain size distribution of syenite was different from that of the fine gravel, being distributed in a larger range of diameters, and with a lower fraction of fines. This factor may contribute to concrete segregation and lower mechanical strength. It was noted density difference between fine gravel and syenite, so it was expected that the concrete with syenite could present increasing values of density as the level of syenite increased. However, the higher porosity of the syenite may lead to higher water consumption in the concrete, which can lower its final mechanical strength.

Results of chemical analysis and $\mathrm{pH}$ evaluation can be seen in Table IV. The chemical compositions of both materials presented differences as well; such differences may impact directly the deflocculating process of the material. For example, the $\mathrm{SiO}_{2}: \mathrm{Na}_{2} \mathrm{O}$ relation in the gravel

Table II - Accumulated grain size analysis of the aggregates.

\begin{tabular}{cccc}
\hline $\begin{array}{c}\text { Opening } \\
(\mathrm{mm})\end{array}$ & $\begin{array}{c}\text { Coarse } \\
\text { gravel }(\%)\end{array}$ & $\begin{array}{c}\text { Fine gravel } \\
(\%)\end{array}$ & $\begin{array}{c}\text { Syenite } \\
(\%)\end{array}$ \\
\hline 25.00 & 0.00 & 0.00 & 0.00 \\
19.00 & 1.59 & 0.00 & 0.00 \\
12.50 & 50.47 & 0.00 & 0.78 \\
9.50 & 80.87 & 0.00 & 1.84 \\
6.30 & 97.03 & 0.04 & 4.22 \\
4.80 & 99.09 & 0.29 & 6.73 \\
2.40 & 99.82 & 15.07 & 23.15 \\
1.20 & 99.82 & 36.33 & 41.32 \\
0.60 & 99.82 & 59.81 & 56.50 \\
0.30 & 99.82 & 90.86 & 72.32 \\
0.15 & 99.82 & 97.97 & 87.18 \\
Pan & 100.00 & 100.00 & 100.00 \\
\hline
\end{tabular}

Table III - Physical properties of the aggregates.

\begin{tabular}{ccccc}
\hline Material & $\begin{array}{c}\text { Bulk } \\
\text { density } \\
\left(\mathrm{kg} / \mathrm{m}^{3}\right)\end{array}$ & $\begin{array}{c}\text { Solid bulk } \\
\text { density } \\
\left(\mathrm{kg} / \mathrm{m}^{3}\right)\end{array}$ & $\begin{array}{c}\text { Water } \\
\text { absorption } \\
(\%)\end{array}$ & $\begin{array}{c}\text { Apparent } \\
\text { porosity } \\
(\%)\end{array}$ \\
\hline Gravel & 2570 & 2590 & 0.35 & 0.89 \\
Syenite & 2710 & 2780 & 0.91 & 2.46 \\
\hline
\end{tabular}

Table IV - Chemical composition (wt\%) and $\mathrm{pH}$ of aggregates.

\begin{tabular}{ccc}
\hline Compound & Gravel & Syenite \\
\hline Loss on ignition & 2.71 & 0.58 \\
$\mathrm{Al}_{2} \mathrm{O}_{3}$ & 19.79 & 14.15 \\
$\mathrm{SiO}_{2}$ & 54.44 & 55.08 \\
$\mathrm{TiO}_{2}$ & 0.75 & 2.95 \\
$\mathrm{Fe}_{2} \mathrm{O}_{3}$ & 3.72 & 4.65 \\
$\mathrm{CaO}$ & 2.09 & 5.75 \\
$\mathrm{MgO}$ & 0.48 & 2.61 \\
$\mathrm{Na}_{2} \mathrm{O}$ & 7.32 & 3.14 \\
$\mathrm{~K}_{2} \mathrm{O}$ & 7.41 & 7.79 \\
$\mathrm{~F}$ & - & 1.02 \\
$\mathrm{P}_{2} \mathrm{O}_{5}$ & 0.08 & 0.87 \\
$\mathrm{BaO}_{\mathrm{SaO}}$ & 0.23 & 0.50 \\
$\mathrm{SrO}_{\mathrm{ZrO}}$ & 0.20 & 0.44 \\
$\mathrm{MnO}_{\mathrm{SO}}$ & 0.12 & 0.12 \\
$\mathrm{Cr}_{2} \mathrm{O}_{3}$ & 0.27 & 0.10 \\
$\mathrm{Nb}_{2} \mathrm{O}_{5}$ & 0.08 & 0.08 \\
$\mathrm{Cs}_{2} \mathrm{O}$ & - & 0.06 \\
$\mathrm{ZnO}_{20}$ & 0.25 & 0.05 \\
$\mathrm{Au}$ & - & - \\
$\mathrm{Y}_{2} \mathrm{O}_{3}$ & - & - \\
$\mathrm{pH}$ & 9.60 & 0.05 \\
\hline & & 0.01 \\
\hline
\end{tabular}

was 7.43, while in syenite was 17.54. This difference may affect the required amount of water and/or additive, interfering in the final properties of the concrete [14]. $\mathrm{pH}$ also has its influence, and the change may lead to concrete segregation depending on the amount of additive used.

Cohesion evaluation: for all formulations, cohesion was visually analyzed. The appearance of the material may be seen in Fig. 1. From these images, it can be noted that keeping the same level of water, there was no segregation in the concretes due to the adjustment made with the algorithm. It was possible to substitute $100 \%$ of fine gravel by syenite, which could have caused segregation in levels superior to $50 \%$, as observed in [15].

Compressive strength: compressive strength results may 

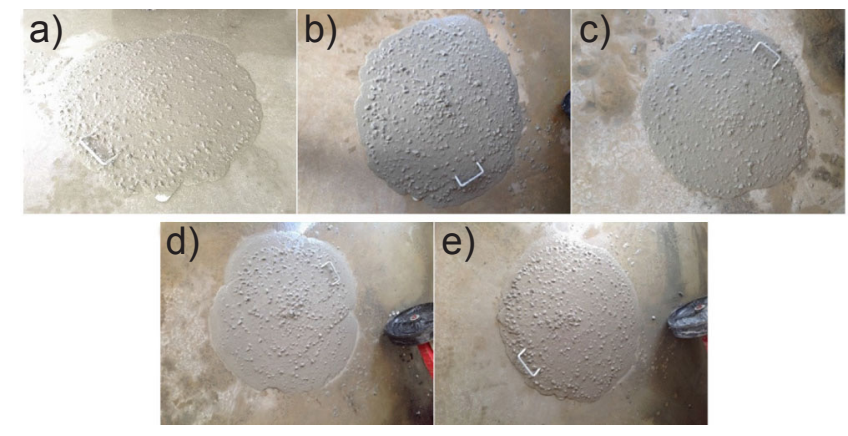

Figure 1: Cohesion evaluation for formulations: a) C1; b) C1-25; c) C1-50; d) C1-75; and e) C1-100.

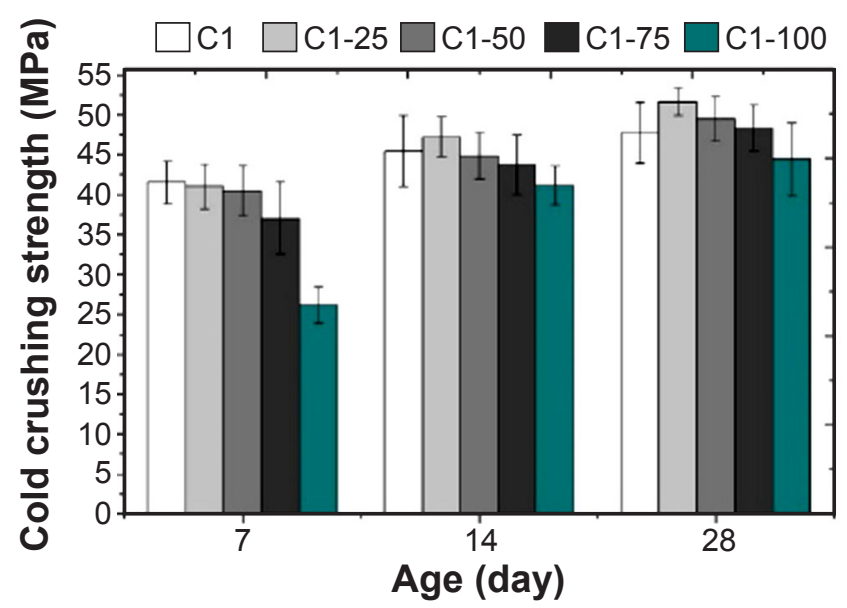

Figure 2: Compressive strength of formulations with syenite after 7,14 and 28 days.

be seen in Fig. 2. It can be observed that mechanical strength tended to lower with the addition of syenite; however, the lowest value after 28 days was still superior to $35 \mathrm{MPa}$, which was the strength expected due to the type of cement and dosage used. Thus, it can be stated that the addition of syenite does not affect the mechanical strength of the concrete, as long as an adequate formulation is used, what was achieved using the algorithm developed.

\section{CONCLUSIONS}

The use of mathematical models for concrete formulations, such as the method of Andreasen, is viable, and the level of water and additive also impact directly the final quality of the product. The use of the algorithm developed for correction of aggregate proportion in order to keep granulometric distribution was essential, since the final properties of the concrete are strongly dependent on the grain size distribution. It affects the required water and concrete cohesion, which have a direct impact on mechanical strength. This was proved by the values of compressive strength found after 28 days: the expected value of compressive strength according to the cement dosage used was $35 \mathrm{MPa}$, and values $27 \%$ to $47 \%$ higher were found for all formulations tested. All formulations analyzed presented good properties for concrete, such as good cohesion and mechanical strength, resulting possibly in the reduction of cost with the increase of syenite content.

\section{ACKNOWLEDGMENTS}

The authors are thankful to FAPEMIG and CAPESBrazil for the financial support for this work.

\section{REFERENCES}

[1] P.B. Fusco, Tecnologia do concreto estrutural: tópicos aplicados, Ed. Pini, S. Paulo (2008).

[2] W. Meng, M. Valipour, K.H. Khayat, Mater. Struct. 50, 1 (2017) 29.

[3] P.H.R. Borges, L.F. Fonseca, V.A. Nunes, T.H. Panzera, C.C. Matuscelli, J. Mater. Civil Eng. 26 (2014) 692.

[4] A.M. Neville, Propriedades do concreto, $5^{\text {th }}$ ed., Bookman Ed., Porto Alegre (2016).

[5] I.R. Oliveira, A.R. Studart, R.G. Pileggi, V.C. Pandolfelli, Dispersão e empacotamento de partículas, Fazendo Arte, S. Paulo (2000).

[6] L. Granzotto, R.A. Souza, Acta Sci. Technol. 35 (2013) 39.

[7] R. Siddique, Y. Aggarwal, P. Aggarwal, E.-H. Kadri, R. Bennacer, Constr. Build. Mater. 25 (2011) 1916.

[8] M. Singh, R. Siddique, Constr. Build. Mater. 50 (2014) 246.

[9] C.D. Roveri, L.H. Godoy, A. Zanardo, L.L. Silva, M.M.T. Moreno, F.C. Navarro, Rev. Inst. Geológ. 34 (2013) 27.

[10] R.H.F. Grillo, Mater. Sci. Forum 881 (2016) 233.

[11] NBR NM 67, "Concreto: determinação da consistência pelo abatimento do tronco de cone", Rio Janeiro (1998).

[12] NBR 5738, "Concreto: procedimento para moldagem e cura de corpos de prova", Rio Janeiro (2015).

[13] NBR 5739, “Concreto: ensaio de compressão de corpos de prova cilíndricos", Rio Janeiro (2007).

[14] M. Link, S.R. Bragança, C.P. Bergmann, Cerâm. Ind. 18 (2013) 25.

[15] P.M. Godinho, in $60^{\text {th }}$ Braz. Congr. Ceram., Águas de Lindóia (2015).

(Rec. 04/08/2018, Rev. 30/10/2018, Ac. 11/11/2018) 